\title{
BRICOLAGE \\ Exploring How Islam is Understood and Lived in Java
}

\author{
Afida Safriani \\ IAIN Sunan Ampel, Surabaya - Indonesia
}

Book Review

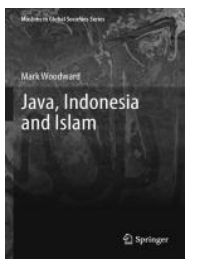

\author{
Book title : Java, Indonesia and Islam \\ Author : Mark Woodward \\ No. of Pages : xiv +275 \\ Year : 2011 \\ Publisher : Springer Science + Business media
}

The book "Java, Indonesia, and Islam" comprises of essays that were written throughout three decades of the writer's ethnographic research in the Sultanate of Yogyakarta and other regions of the Indonesian island of Java as well as on his close readings of contemporary and historical Indonesian Islamic texts. Mark Woodward, the writer, basically seeks to illustrate how Islam is understood and lived in Java. He also portrays how Java and Indonesia as conceptual categories, geographic and political entities inform and shape each other, and how this interaction influences the understanding and experience of Islam among people who find themselves inhabiting both worlds simultaneously.

The first chapter of the books describes Yogyakarta in terms of religion, culture and nationality. While Indonesia is a republic, Yogyakarta is a kingdom with all internal power and authority remaining in the hands of the Sultan. Issues of religion, culture and nationality were all at stake in this exchange. They have reverberated through the histories of both nations for more than 60 years, surfacing in 2008 in debates concerning the still unresolved status of the Sultanate in the Indonesian Republic. In Yogyakarta the balance is 
thrown not only by the complex interrelations of culture and religion as emic categories in Indonesian and Javanese discourse, but also by the fact that there are competing nationalisms: Indonesian nationalism and Yogyakarta nationalism.

This chapter further explains that the Indonesian terms agama, kebudayaan and kebangsaan are only roughly translated as religion, cultural and nationality. All the three are socially and politically constructed categories the boundaries of which have shifted considerably over time and which are still very much in flux and at issue. The term kebangsaan refers to a nation, people or ethnic group and in contemporary Indonesian discourse has all three connotations. Yet, agama and kebudayaan are more complex still.

Questions of what is "religion" and what is "culture" may, at times, be bitterly contested. In the 1970s much of what is described in this book was often referred to as "Javanese Religion" (Agama Jawa). Proponents of what was formerly Javanese Religion are willing to accept the designation Javanese Culture to avoid antagonizing orthoprax, and especially modernist and Islamist, Muslims. Similarly, many orthoprax Muslims have sought to describe this complex as "Javanese Islamic Culture" for similar reasons. But, shifts in the boundaries between "culture" and "religion," can have important consequences for understanding the dynamics of power in Javanese and Indonesian society.

Chapter two concerns the religious and cultural foundations of Javanese traditional medicine. Unlike Geertz's analysis that considers Javanese curing as the animistic substratum of Javanese religion, this book argues that Javanese theories of health, illness and curing are based on a Muslim world view and theory of personhood. The pervasive influence of Muslim theology, doctrine and mysticism on Javanese curing indicates that while it is possible to isolate what can be called a traditional medical system, medical knowledge and practice do not comprise discrete domains in Javanese culture. The book continues to outline that many of the abstract concepts of personhood, cosmology, power and knowledge that form the basis of the Javanese medical system derive ultimately from Middle Eastern Muslim scriptural traditions while others are rooted in older Hindu-Javanese traditions.

Specifically, the Javanese medical system draws on a wide variety of symbols, roles and interactional patterns, none of which may be 
understood as uniquely medical. Medical pluralism is, therefore, and inherent feature of Javanese traditional medicine. There are two primary modes of medical practice. One, rooted in Sufi concepts of sainthood (wali) is based on Islamic mystical concepts of miracles and gnosis. The other, practiced by dukun (curers) involves the use of morally suspect forms of magical power some of which are derived from

Hindu-Javanese traditions and others are uniquely Javanese or at least Malay. Furthermore, the Javanese health care system includes complex theories of anatomy, the origin and treatment of disease, a large number of herbal and mineral medicines and a system of social interaction directing potential patients towards specialists who treat only a small subset of the culturally recognized ailments. The system is, however, fundamentally paradoxical. Many Javanese are afraid of dukun considering them to be dangerous as well as powerful. Several curers interviewed in and around Yogyakarta use variety of terms to which they refer other than dukun. They referred to themselves as "helper" (pitulung), "mystic" (ahli kebatinan), "expert in Javanese science" (abli ngilmu Jawa), "elder" (orang tua), "smart person" (orang pintar) or some similar term. Today they are often referred to as "para-normals" ( paranormal) or practitioners of "alternative medicine" (pengobatan alternatiff). On the other hand, traditional healers with strong Islamic orientations call themselves "religious teacher" (ustads), "wise man" (babib) or "Arabic physician" (tabib).

Even kyai are also said to have the ability to heal and exorcise demons. Wali, kyai, mystics and other holy men and dukun are all thought to have the ability cure diseases of the physical and spiritual bodies. The difference between these modes of medical practice is that saints, mystics and other holy men do not rely on magical power or spirits.

Chapter three explores the slametan. The writer could not agree more with Geertz that it is the 'core ritual' of Javanese culture. Nevertheless, he argues that the slametan cannot be identified as an animistic rite the purpose of which to reinforce social solidarity and as being primarily a village ritual. He therefore presents an alternative interpretation of the slametan as an example of a ritual complex that links blessing (barakah) and food and extends from Arabia to Southeast Asia. He explains that the slametan is not primarily a village ritual and that its religious and social goals are defined in terms of Islamic 
mystical teachings. He further argues that Geertz' analysis of the slametan that assumes that ritual meals are characteristic of animism but foreign to Islam is not true.

In connection with Javanese of all theological orientations who believe that feeding the poor is a religious obligation and a source of blessing, kejawen Muslims take pains to invite poor people to slametan or, at least, to send them some of the food. Many also donate uncooked rice and other foods to augment the small amounts of sacred food distributed at the ritual. Some of them feel that the food distributed in the slametan is of greater importance than the rakat as the slametan food is referred to as a "gift from heart" stemming from a deep desire to help one's fellow humans with no expectation of return.

The slametan itself, as ritual meals, parallels the Indo-Persian kanduri, Javanese kenduren, Malay kenduri, Acehnese kanduri, Urdu kanduri in terms of the purpose and the way they are conducted. Like the slametan, it also includes recitation of portions of the Qur'an, the distribution of blessed food, and prayers for saints and the local community. In Yogyakarta, The slametan is not exclusively, or even primarily, a village ritual. Nor is it limited to the kejawen community. Slametan are performed in mosques, at pesantren, at the graves of saints, and in the homes of traditional santri. Based on this argumentation, the writer argues that the slametan as a village ritual that loses much of its force in urban environments described by Geertz is misleading.

In short, the slametan provides an example of the complexity of local Islams. The ritual of slametan can be understood as the product of bricolage through which concepts derived from various Muslim textual and ritual traditions and elements of Islamicate culture that transcend locality are fused with things specifically Javanese. There is not one Javanese Local Islam. There are many. Some consider the slametan to be an essential component of Islam, others believe it to be bid'ah, khurafah and shirk: unlawful religious innovation, unbelief and polytheism. In the late 1970s the slametan was often referred to it as being an element of Islam Jawa or Agama Jawa.

Chapter four examines the architectural, political and religious symbolism of the Yogyakarta kraton. The kraton is basically a Javanese house, but a very special one. It is the house of the Sultan who is understood as being Allah's representative on earth and as the "perfect man" of classical Sufism. In general, the religious and political significance of the Javanese kraton resembles that of the royal palaces 
of the Indianized states of mainland Southeast Asia and pre-Islamic Java. However, the Javanese kraton is not a replica of a cosmic mountain. Nor is it arranged as a mandala or set of concentric circles. Its architectural and geometric form is linear, comprising a series of gates and passages oriented on a north-south axis. The cosmic structure depicted in the Yogyakarta kraton is that of a Javanese variant of Islamic mysticism.

Historically, the kraton is said to have been designed by Sultan Hamengkubuwana I. It is a complex, polysemic symbolic system weaving the diverse threads of Javanese religious and political thought together into a single coherent system focusing on the person of the Sultan. Moreover, the kraton is a text, but it is more than a text. It is the sacred precinct defining the state and society. In this respect it is the analog of the Ka'ba at Mecca which is the center and axis mundi of the Muslim world as a whole. Just as the Ka'ba defines the Muslim community as a totality, the Yogyakarta palace defines the Sultanate as a local Muslim community, with the Sultan, who is also known as Kalifutallah (the Caliph or representative of God) as its head.

The architecture and symbolism of the Yogyakarta Kraton are based on a similar understanding of the heart, the Ka'ba and the descent and ascent of the perfect man. These are among the most esoteric of Sufi teachings. They are important in Java in part because of their mystical significance, but also because they are the basis of the Javanese/Islamic theory of kingship.

The kraton is a model of the body of the perfect man and the paths leading to perfection. The kraton has nine gates which represent the openings in the human body which according to Serat Wirid must be closed in meditation as well as in Muslim mortuary ritual.

The representation of the human body in the architecture and symbolism of the kraton is illustrative of the influence of Sufi understandings of relationships between humanity and divinity in Javanese religious thought. The southern third of the kraton depicts the descent of the perfect man from the divine essence and the birth of a royal infant. The northern third of the palace is a model of introspective and cosmological formulations of the mystical path. Many of the symbols of this section of the kraton are trees and other mundane objects which are linked to the Sufi doctrine of the descent of the perfect man by means of pseudo-etymologies. 
Chapter five portrays the way in which the Yogyakarta Kraton celebrates one of the most important Muslim holy days, Mawlid alNabi, which commemorates the birth of the prophet Muhammad. In specific, this chapter is concerned with the history, religious meanings, and performative structure of this ritual complex, known locally as the Garebeg Malud, in Yogyakarta. The Malud is among the most important, and today certainly the most popular of the Yogyakarta state ceremonies.

In addition to its stated purpose of celebrating the birth of the Prophet Muhammad, the Yogyakarta Garebeg Malud serves four basic purposes: it makes symbolic statements about the Islamic legitimacy of Javanese kingship; it establishes a chain of blessing linking the state and its people with the Sultan, local saints, Muhammad, and God; it links Javanese mysticism with Essentialist Islam and; and it mediates between a religiously inspired theory of kingship and changing political and economic conditions.

In line with the slametan, The Garebeg Malud is a series of slametan at which the Sultan offers food to his subjects. It is thought to transform social relations in the Sultanate in the same way that slametan transform local communities. In rural Java the Mawlid is celebrated with a slametan called Maludan. Therefore, the Maludan and the Garebeg Malud have much in common. Seen from the kraton, the Slametan Maludan is the Garebeg Malud stripped of its royal indexical symbols. Seen from the village, the Garebeg Malud is a Maludan with royal indexical symbols attached.

In addition to the Garebeg Malud is Sekaten, a combined fair, night market, and religious observance. The night market, at which there are a wide variety of popular entertainment events, runs for an entire month. Sekaten itself lasts for 7 days, culminating in the Sultan's visit to the Grand Mosque the evening prior to the Garebeg. Elite components of Sekaten include a religious observance and ritual meal attended by the Sultan, court officials, and 'ulamā'. On the final evening of Sekaten there is a procession from the palace to the state mosque.

Chapter six presents the place of the fasting month of Ramadan in Islamic discourse, religious practice and experience in Yogyakarta. In particular, this chapters is concerned not only with the ways in which the fast is observed and celebrated in Yogyakarta, but also with the 
ways in which it serves as a symbolic marker of differentiation within the Javanese Muslim community.

In particular, Javanese observances of the rites of Ramadan fall into three general categories. Those of reformists which are limited to rites prescribed by Islamic law (with the except of Halal Bihalal,) those of traditional santri add a complex set of locally defined devotional acts and finally those of kejawen Muslims who often neglect Shari'ah regulations but who join enthusiastically in superogatory acts of piety. Despite these differing performance styles, Ramadan observances are motivated by a common understanding of the purpose and benefits of the fast and share a common ritual structure, i.e., that Ruwah purifies the physical body, Ramadan cleanses the spiritual body of sin and that Sawal transforms social relations.

The last chapter explores the interplay of kebudayaan and agama in Yogyakarta at the end of the New Order and the ways in which Sultan Hamengkubuwana X used the kraton as a stage for cultural/religious/political drama that figured significantly in the process of Reformasi that led to the democratic transformation of 1998.

Through this chapter, it is argued that Yogyakarta remained peaceful compared to Jakarta and other neighboring royal cities in Surakarta in dealing with the crisis of 1998. This was possible to happen because Yogyakarta's history as the "mother city" of the Indonesian revolution and the charisma of the Yogyakarta throne enabled Hamengkubuwana $\mathrm{X}$ to draw on a mix of religious, cultural and nationalist symbols of legitimacy in defiance of a regime that by May of 1998 could rely only on brute force to remain in power. This bricolage enabled the Sultan to work together with 'ulamà' and Muslim politicians of diverse theological orientations to maintain peace and order in a time of chaos. It also enabled him to define what began as an economic and political crisis as a cosmic struggle between good and evil; between Yogyakarta and Jakarta and between himself and President Suharto

Throughout this volume, the writer argues the Javanese and larger Indonesian discourse about agama and kebudayaan is of more general methodological and theoretical significance. He suggests that while the manner in which emic cultural categories are structured is of significance for Anthropologists, and especially for Cognitive Anthropologists, it may be of less importance for Religious Studies scholars. He further explains that it is essential for the study of religion 
to take account of these categorizations and not to limit their analysis to what is locally defined as "religion". It is especially important given the inherent tendency of religions to segment. To accept what one sectarian or political group claims about others and the category religion is a fatal analytic error. He particularly puts Clifford Geertz and others seriously misunderstood and misrepresented Javanese Islam by accepting the definition of "Islam" proposed by neo-fundamentalists as an analytic category.

In term of the content, this book is very rich, discloses almost all kinds of the cultural practices in Java and discovers how Islam lives in the Javanese culture. This book becomes very valuable and priceless for those who are interested in understanding Islam in Indonesia because it provides 'local flavour' that makes it different from how Islam is practiced in other countries. However, despite of the detail portrait of Javanese Islam in Yogyakarta, this book does not adequately present Javanese Islam elsewhere in Java but Yogyakarta. As the writer himself admitted that he is, however, 'cognizant' of the incompleteness of ethnography as a method for understanding this reality. [] 